\title{
Balkanologie
}

Balkanologie Revue d'études pluridisciplinaires

Vol. III, n 1 | 1999

Volume III Numéro 1

\section{Elite Transformation and Democratic Transition in Macedonia and Slovenia}

\section{Židas Daskalovski}

\section{(2) OpenEdition}

1 Journals

Electronic version

URL: http://journals.openedition.org/balkanologie/281

DOI: 10.4000/balkanologie.281

ISSN: 1965-0582

\section{Publisher}

Association française d'études sur les Balkans (Afebalk)

Printed version

Date of publication: 1 July 1999

Number of pages: 5-32

ISSN: 1279-7952

\section{Electronic reference}

Židas Daskalovski, «Elite Transformation and Democratic Transition in Macedonia and Slovenia »,

Balkanologie [Online], Vol. III, n 1 | 1999, Online since 04 June 2008, connection on 17 December 2020. URL : http://journals.openedition.org/balkanologie/281; DOI : https://doi.org/10.4000/balkanologie 281

This text was automatically generated on 17 December 2020.

(c) Tous droits réservés 


\title{
Elite Transformation and Democratic Transition in Macedonia and Slovenia
}

\author{
Židas Daskalovski
}

1 The process of democratization of the Eastern European countries has been recent focus of attention of a number of political scientists ${ }^{1}$. Among the various authors writing on the issue of democratic transition in post-communist Europe very few have concentrated on the processes of democratic transition and consolidation in former Yugoslavia ${ }^{2}$. Out of the few authors who did analyze the question of democratic transformation of the countries that came into existence with the dissolution of the second Yugoslavia, few of them have attempted to correlate this process with interrepublican discussions about the future status of Yugoslavia.

2 The aim of this paper is to explain the distinct democratic transition of Slovenia and Macedonia using Adam Przeworski's theory of democratization, and to show the importance of the elite's responses to the questions and issues raised on federal level concerning the status of second Yugoslavia to the fore-mentioned process ${ }^{3}$. This paper will underline the importance of elite transformation on the democratization process in Macedonia and Slovenia for two main reasons : first of all, only few studies have delt with these two former Yugoslavian republics, and, secondly, these republics were the most opposite of the former Yugoslavia.

\section{Some Methodological Concepts}

3 Przeworski divides the process of democratic transition into two phases. In the first stage, labeled liberalization, authoritarian regimes brake down and democracy appears on the political agenda ${ }^{4}$. In the second phase, democratization, the new political leadership focuses on the formation of democratic institutions. A new constitution is a result of the negotiations between the representatives of the opposition and the ancien regime. Stability and fairness of the constitution and the other new institutions 
depends on the power positions of the negotiating parties, and whether these relations are generally known. According to Przeworski, the case when the power relations are not known or are unclear, is best ; then the political authors negotiate more balanced political institutions. These type of institutions are also more prone to last longer and under different circumstances ${ }^{5}$. Finally, Przeworski, maintains that democracy, after the establishment of democratic institutions, still faces challenges of an unbalanced ratio of political forces within a society. For example, if the opposition stages general strike every time it loses elections or the government adopts unfavorable policy, then the democratic institutions might be weakened, and the military might step in $^{6}$. A solution to this problem, Przeworski argues, is political pacts, agreements among «leaders of political parties to divide government offices among themselves independent of election results, fix basic policy orientations, and exclude and, if need, be repress outsiders ${ }^{7}$.

4 Using Przeworski's theory this paper will show how both Macedonian and Slovenian elites in the debates in post-Tito Yugoslavia promoted and defended their own national interests vis-à-vis the interests of the other Yugoslav republics, and how at the peak of the debates, in the late 1980 's, both agreed to liberalize the political system in order to broaden and legitimize their support in the federal negotiation processes. Confident that they would win multi-party elections in their respective republics, both the Macedonian and the Slovenian communist elites miscalculated the potential strength of the parties and groups which had stronger national agendas than their own. Consequently, the mixed, uninstructed results of the first democratic elections in Macedonia and Slovenia, in opposition for example to those in Serbia and Croatia where one single party came to dominate the presidency and the parliament, together with the international responses to the Yugoslav process of dissolution, would have significant impact on the democratization processes in both countries. Soon after the first free elections, both Macedonian and Slovenian elites would choose a stable new institutional frameworks and form political pacts with the emerging opposition parties, resulting in strengthening of the democratization processes in both republics. However, as Higley and Burton argue, stable democracies do not emerge only by writing constitutions, and founding new institutional frameworks; the progress is also facilitated by what they term change in status of political elites: from disunified to consensually unified elite types.

5 According to Higley and Burton there are three different kinds of elite types ${ }^{8}$, consensually unified, ideologically unified, and disunified elites 9 . Consensual elites are characterized by inclusive structural integration and value consensus ${ }^{10}$. These types of elites might take opposing policy stances in public, but consistently refrain from extending their disagreements to a point of violent conflict. Disunified elites, on the other hand, are characterized by minimal structural integration and value consensus. Fractions of disunified elites distrust each other, engage in ruthless, often violent conflicts, and do not cooperate to hold back societal divisions or to avoid political crisis $^{11}$. Ideologically unified elites are typical for authoritarian countries, where structural integration and value consensus are seemingly monolithic. Thus, ideologically unified elites appear to have complete union, publicly support the same policies, and are members of a centralized party or movement.

6 Consequently, Higley and Burton maintain that the "ideal" kind of elites is the consensually unified type, and that the critical step for a successful democratization 
includes transformation of disunified elites into consensually unified ones. In post 1989-1990 Eastern Europe there were two main ways in which consensually unified national elites could form: through a direct transformation, or through an elite settlement of basic disputes among elites. A direct transformation can occur if the party elites acknowledge the counter productivity of communist ideology, embrace democracy, and accommodate the emerging new elites ${ }^{12}$. This transformation is also possible through an elite settlement, « a relatively rare event in which warring national elite factions suddenly and deliberately reorganize their relations by negotiating compromises on their most basic disagreements ${ }^{13}$. The settlement occurs through relatively quick negotiations among leaders of major elite factions. These negotiations are conducted by experienced political leaders and result in formal written agreements ${ }^{14}$. A number of circumstances might foster this trend: an emergence of democratic ethos, a strong pro-Western orientation, pragmatism, new orientations on the part of the former communists elite in favor of economic liberalization and political democracy, and, conflict resolution with cooperation among new and old elites, and thus solidarity sentiments ${ }^{15}$. Once this elite unity and consensus is reached, stable democracies are feasible, but may also not ${ }^{16}$.

7 Macedonian and Slovenian elites achieved consensus and unity by combination of aspects of both direct transformation to consensual unity and elite settlement. In the late 1980's both Macedonian and Slovenian elites embraced democracy, thus disregarding old communist ideology. They, both, however, in the aftermath of the 1990 elections, negotiated elite settlements with the new elites. Nonetheless, the different Macedonian and Slovenian elites' policies and strategic responses before and during the Yugoslav crisis, would have a great impact on the Macedonian and Slovenian paths to democratic consolidation. While the Slovenian elites would be able to concentrate on the issues of democratic restructuring and economic consolidation only, the Macedonian elites would face additional problems of international recognition, economic sanctions, and minority dilemmas.

\section{Yugoslav Debates : 1980-1988}

8 Kardelj's and Tito's deaths (in 1979 and 1980) and the growing economic crisis in Yugoslavia in the beginning of the 1980's largely influenced the reemergence of the issues of liberalization and nationalism, already raised on republican level and suppressed by Tito in the late 1960 's and early $1970{ }^{\prime} \mathrm{s}^{17}$. The question of liberalization, both in terms of economic transformation and power legitimization, was intertwined with the issue of republican interests, the status of the Yugoslav state, and thus, regional nationalism ${ }^{18}$. During 1980's the regional Yugoslav communist leaders tried to achieve almost impossible goals : to restructure the federation so that it fits different republican interests, to modernize the economy, and, lastly, to (re)legitimize their power authority.

9 As a result of the events in the late 1960's and the beginning of the 1970's, Tito compromised with the dissident voices within the communist party and, in 1974, brought a constitution which de facto decentralized the country and the communist power instrument, the League of Communist of Yugoslavia (LCY $)^{19}$. Therefore, the 1980's discussions within the LCY were not debates among federally unified communists but between regional communist party leaders seeking to defend their 
own republican interests. Although each regional party leadership was fractionated to some extent, in the initial phase of the debate, in the beginning of the 1980's all of the republican communist elites opted for specific positions ; thus, while the Slovenian and Vojvodinian leaders advocated liberalization and even greater Yugoslav decentralization, the Serbian leaders strongly favored liberal centralization, while the Macedonian, Croatian, and Kosovar parties preferred maintenance of the status quo, i.e., decentralized communist Yugoslavia ${ }^{20}$.

10 In search for options how to deal with the crisis, in the beginning of the 1980's Yugoslav communists began the process of (re)legitimatization of the regime which would eventually lead to the democratization of the country. Different options were proposed in the discussions, ranging from proposals for restoration of the multi-party system, to a "party-less" socialist system operated through citizens' associations ${ }^{21}$. Although some propagated even stricter rule of the party, most of the ideas were undoubtedly quite liberal and reform-oriented in character, ranging from calls for establishment of full-fledged "social democracy" to multi-candidate communist elections ${ }^{22}$.

11 Parallel to the liberalization debate, was the discussion on the status of the federation and the value of the 1974 Constitution. Paradoxically, inter-republican discussions over the status of the Yugoslav federation would be the salient cause for the liberalization and the break up of the country. Indeed, the Serbian upsurge of the institutionalized confederate balance of power game would inevitably accelerate the centrifugal processes in Yugoslavia. Serbian's party leadership insistence on re-centralizing Yugoslavia would tip of the status quo and provoke strong chain of reactions, first among the Slovenian, and later among the other Yugoslav republics party leaders, which in turn would directly lead former Yugoslav communists to embrace more radical options as solutions to the crisis : democratization, and dissolution. Drastic changes in the attitude of the Serbian party leadership toward the status of the Yugoslav federation would come about with the rise to power of Slobodan Milošević, exactly in the midst of the federal level discussions on how to overcome the Yugoslav crisis.

Until 1987, it seemed conceivable that while the regional elites would ask for further debate on the future status of the federation, Yugoslavia could continue on a path of slow transformation to pluralism and liberalization. However, the rise of S. Milošević who the same year "succeeded in deposing his erstwhile mentor, Ivan Stambolić, and in establishing himself as the unrivaled boss in the republic of Serbia " would significantly change the situation in the country ${ }^{23}$. Milošević shrewdly materialized on Serbian's people national sentiments and moved to change Serbia's "disadvantaged position" within the Yugoslav federation. Using the ideology of the nationalistic wing of the Serbian intellectuals, and populist methods, in the period between 1988 and 1989, Milošević swiftly abolished the autonomous status of the Kosovo and Vojvodina provinces, and installed his own supporters in the Montenegrin party leadership ${ }^{24}$. By taking control of the Serbian media and establishing "cult of personality" Milošević mobilized the Serbian society in favor of the slogan "strong Serbia, strong Yugoslavia" ${ }^{25}$. After entrenching his power in Serbia and Montenegro, Milošević aimed at changing the federal constitution so that it meets Serbian interests better ${ }^{26}$. Not surprisingly, Serbia's new policies provoked a strong reaction among the other Yugoslav republican leaders; Slovenia among which taking a leading role in opposing 
Milošević. Already in 1988, and especially in 1989, two clear trends among the Yugoslav republics could be gauged; promotion of particular, regional interests through mobilization of a growing pluralist society, and consequently, official endorsement of democratization and multi-party elections to further strengthen and legitimize the republican party leaderships.

\section{Rise of Slovenian Pluralism in the 1980's and Slovenian Elite Response to the Serbian Assertive Role in the Federation}

13 Tito's death signified change in Yugoslav communist power structures. A generation which based its power on the partisan myth, the axiom "brotherhood and unity", and the communist party as the vanguard of the society, was slowly dying out and being replaced by new, and younger party structures. While in Serbia this process lead to the rise of S. Milošević, in other republics, and especially in Slovenia, the generation change provided necessary fuel for the process of liberalization and "pluralization". The combination of ascendance to power of more liberal factions within the Slovenian communist party, and the growing Yugoslav crisis, provided a greater space and more tolerance for the development of different movements and ideas on the Slovenian scene. As a result, a growing "pluralization" of the Slovenian society was taking place in the 1980's.

14 The distinctive transformation to pluralism of the Slovenian society was initiated by the punk movement. This culturally unique phenomenon which found grounds in Slovenia as a sort of a youth subculture, was able to mobilize support in its defense against the more conservative elements in the establishment, and initiate the pluralist way of life within the Slovenian society ${ }^{27}$. The rise of the punk movement was followed by development of a number of other alternative subcultures and social movements : pacifist, feminist, gay, spiritual, etc..$^{28}$ In the late 1980's Radio Student became a medium that was increasingly receptive to different views on life and culture ${ }^{29}$. The transformed communist youth organization weekly Mladina and the new founded intellectual journal Nova Revija further strengthened the dissemination of pluralistic ideas and programs. Furthermore, the Students' Cultural and Artistic Center (SKUC) provided medium for many cultural and artistic productions, including those of Slovenian alternative rock groups such as Borghesia, Pankrti, and Laibach. The foundation of a range of different theaters and the growth of the "graffiti" culture provided an additional dimension of the emerging Slovenian pluralistic society.

The gradual generation change and the rise to power of more liberal fraction within the leadership of the Slovenian communist party in 1986 meant that the new elite would continue to tolerate the blossoming of the Slovenian pluralistic views ${ }^{30}$. In fact, the party elite became appreciative of some of the ideas the Slovenian civil society promoted. As the tension over the future Yugoslav arrangements grew, the Slovenian party elite could only look with approval upon the publication of a series of sixteen articles printed in the special February 1987 issue of Nova Revija as « contributions to the Slovene national program ». Since the program called for a radical improvement of the Slovenian position within the Yugoslav federation, once discussed and supported by the public it could have provided the Slovenian party leaders the needed legitimacy 
and support in the federal debates about the status of the Yugoslav federation ${ }^{31}$. However, initially, the Slovenian leadership did not utilize the Nova Revija "Slovenian National Program" to its advantage, it would only be the Serbian mobilization of forces within the Serbian pluralistic scene, including such variety of groupings as religious and academic institutions, that would lead the Slovenian elites to follow suit and try to effectively mobilize the Slovenian pluralistic society in defense of its interests. This mobilization would necessarily lead the Slovenian party elites to embrace a multi-party elections as an only way in order to legitimize their stance within the Yugoslav debates. More importantly, the Slovenian elites would, by liberalizing, irreversibly turn the pendulum towards democratization of the Slovenian society.

\section{« Macedonian Way » of Pluralism and Macedonian Party Elites Responses to the Yugoslav Crisis}

16 Macedonian "pluralization" took its own form in the 1980's. Devoid of Tito's legacy of suppressing narrow republican interests, Macedonia witnessed rise of plethora of groups, movements, and associations that gradually emphasized elements of Macedonian ethnos and culture that were largely ignored during the previous period ${ }^{32}$. Similarly to Slovenia, first signs of the emergence of new pluralist tendencies were to be found in the Macedonian cultural scene. The emergence of Padot na Vizantija, Macedonian "Byzantine rock" group in the early 1980's followed by the establishment of Aporea, a multimedia "new art" project that underlined the Macedonian language and culture, signalized the birth of a new Macedonian culture ${ }^{33}$. Mizar, another Macedonian "authentic sounds" group founded in 1981, and Padot na Vizantija were the two avant-garde music bands that juxtaposed the vibes of Leb $i$ Sol,the most popular Macedonian rock group, also highly successful on the Yugoslav rock scene. The difference between the two seemed trivial, but it is essential in understanding the rise of a new pluralistic culture in Macedonia; while the former sang in Macedonian and drew inspiration from the wealth of Macedonian historical and folk traditions, combined with the legacy of the Byzantine culture, the latter, sang in Serbocroat and were famous as a great all-Yugoslav band ${ }^{34}$. While the communist party leadership largely ignored the manifestations of the former, still, in contrast to Tito's time when it would have probably outlawed them, now, it did let them perform. During the late 1980's the Youth Cultural Center (better known as "MKC") served as a medium where new "authentic" Macedonian cultural manifestations could take part.

17 Meantime, the Macedonian party elites did, in a sharp contrariety to the general communist tradition of suppressing religion, tolerate a growing assertion of the Macedonian Orthodox Church (MOC) in public life. During the 1980's MOC was able to commence building of a colossal Orthodox cathedral in the center of the Macedonian capital, Skopje. Contrary to what was expected, the Macedonian communist leaders endorsed the project, which was finished only in 1990, with much sympathy from the Macedonian public ${ }^{35}$. Furthermore, in 1987, a group of young Macedonians established, what was fundamentally, a soccer fans association, Komiti ${ }^{36}$. Although largely focused on sport events, this group was vibrant in provoking historical issues and questions concerning the status of Macedonia within the Yugoslav federation. Energized by the successes of the main Macedonian soccer club Vardar (it won the federal championship for the first and only time in the 1986-1987 season) Komiti, in their public gathering 
before and after the soccer matches,raised to the surface of the Macedonian public specific, but during Tito's time largely ignored, if not forbidden to discuss, historical issues $^{37}$.

One of these issues was the treatment of Macedonian minorities in the countries neighboring the Macedonian part of the Yugoslav federation, Greece, Bulgaria, and Albania. Faced with rising nationalistic tensions in Kosovo, and subsequent discussions on federal level about minority rights, Macedonians felt that their own agenda within the Yugoslav federation was being left out. Aegean Macedonians who left Greece during the Greek Civil War and who were not allowed to return to their homes by the Greek government, were vocal in bringing to the public the issue of misconduct of the Macedonian minorities. Following an upsurge of activities of the transnational Macedonian human rights network, active in Greece, USA, Canada, and Australia, an Aegean Macedonian association was also established in Macedonia proper ${ }^{38}$.

19 Founded in 1986, by an initiative of the Aegean Macedonians living in Canada, the Association of Child Refugees from Aegean Macedonia had its headquarters in Skopje and established branches in Romania, Poland, Czechoslovakia, Canada, and Australia ${ }^{39}$. This organization immediately dedicated its activities to the promotion of the status of the Macedonian minority in Greece. In 1988, the association initiated the idea of holding a gathering of all those Aegean Macedonians who were forced to leave Northern Greece in the course of the Greek Civil War and were unable to return to their home land because of the discriminatory policies by the Greek government. Under pressure of the Greek foreign ministry the Yugoslav federal authorities initially opposed the meeting and asked the Macedonian party either to postpone it or to cancel it. When the Macedonian leadership answered that if the Yugoslav government insisted on canceling the meeting, it would resign, the federal government, fearing public unrest in Macedonia, stopped pressing the matter further, and the reunion took place, in Skopje, between $30^{\text {th }}$ June and $3^{\text {rd }}$ July of $1988^{40}$. The First International Reunion of Child Refugees of Aegean Macedonian adopted a resolution urging the Greek government to allow Macedonian political refugees who left Greece after the Greek Civil War to return to Greece. Furthermore, in late June and early July 1988 a large demonstration of Macedonians who had left Greece as children in 1948 took place in Skopje, capital of the Republic of Macedonia. This demonstration was attended by several thousand Macedonians from all over the world and repeated on August 10, 1988 , on the $75^{\text {th }}$ anniversary of the division and partition of Macedonia, when a large protest by Macedonians was held in front of the UN building in New York.

The national agenda was soon picked up by the leading members of the Macedonian PEN Association and reformulated in their writings and meetings. Due to pressure by the Macedonian association, in June, 1986 at its $49^{\text {th }}$ Congress, the international writers' organization, PEN, condemned the denial of the Macedonian language by Greece and sent letters to the Greek PEN Centre and the Greek Minister for Culture. In addition, the dailies Nova Makedonija and Večer became admissible to public discussions on the country's dilemmas and begun publishing articles on issues like minority and human rights and pro's and con's of market economy and democratic reform. The Macedonian youth communist's journal, Mlad Borec, together with the reformed newspaper of the League of Communists of Macedonia, the weekly Magazine 21, also provided space for articulation of pluralistic views on the nature of the Macedonian society and its place within the Yugoslav federation. Moreover, several young, well-endowed journalists of 
Mlad Borec reevaluated and criticized the long rule of the Macedonian nomenklatura and begun covering taboo issues like the question whether Macedonia should remain in the Yugoslav federation, pursue confederate status, or become an independent state ${ }^{41}$.

The Macedonian political elites looked upon with sympathy to the gradual proliferation of pluralistic views in Macedonia. They sought to instrumentalize the "pluralization" to their needs, tolerating critique as long as it did not directly threatened party interests. However, at the moment when the Yugoslav crisis deepened to an extent that the Serbian and the Slovenian leadership mobilized their societies and promoted two diametrically antagonistic options to solve the Yugoslav crisis that were unacceptable to Macedonia, the Macedonian elites made use of the growing Macedonian pluralistic society to legitimize and magnify the Macedonian public support for their position in the federal level debates. Combining advancement of a relatively reasonable policy towards the solution of the Yugoslav crisis, and image of the party as of one that cares for and affirms the Macedonian national interests, the Macedonian party elite estimated that it would inevitable carry victory in a multi-party elections ${ }^{42}$. However, they could not correctly foretell the potential power of the even more national oriented forces within Macedonia.

\section{Serbia vs. Slovenia 1989-1990 ; Slovenia Liberalizes}

Meantime, as Yugoslavia witnessed debates on federal level about the solutions to the growing crisis, both Macedonian and Slovenian societies were experiencing a period of "pluralization." The open question was how would the Macedonian and Slovenian elites react to this phenomenon in light of the strong Serbian nationalist tendencies. Faced with growing Serbian nationalism mounting during whole of 1988, Slovenian elites responded equally energetically opposing Serbian demands for centralization of Yugoslavia with counterproposals for special Slovenian status within the federation and by mobilizing the increasingly pluralistic Slovenian society ${ }^{43}$. Throughout 1988 Slovenian elites increasingly talked about the "asymmetric federation model" in which Slovenia would have enjoyed special prerogatives against the other Yugoslav republics ${ }^{44}$. For example, in contrast with the wide spread practice that soldiers of the federal army served in a different republic than the one they were from, the Slovenes asked for special Slovenian military district where all Slovenian conscripts would serve. In opposition to the common use of Serbocroat in the Yugoslav military units, in the new proposed district the solely language of command should have become Slovenian. In short, Slovenia envisioned a system of uneven constitutional arrangement of the Yugoslav federal units, a system which would have made Slovenia's relations to the rest of the federation confederate ${ }^{45}$.

The mobilization of the Slovenian public can be traced to the trial of the four journalist of Mladina, Janez Janša, Ivan Borstner, David Tašič, and Franci Zavrl for publishing secret army files, in June 1988. Conducted in Serbocroat the proceedings deeply irritated the Slovenes. The Slovenian leadership implicitly supported public protest rallies and encouraged, if not initiated, the foundation of the "Independent Committee for the Protection of Human Rights" ${ }^{\prime 6}$. This committee issued periodical bulletins in English and protest petitions. Support for the four indicted was quickly generated by the Slovenian Peasants Union, the local trade union, and the Slovene Bishops' Conference of the Catholic Church. Moreover, the Slovenian party elites tacitly 
approved a large mobilization of the Slovenian public that took a form of a protest rally against the military trial. On June $22^{\text {nd }}, 40000$ people, an enormous figure for small country like Slovenia, demonstrated on Ljubljana's Liberation Square against the unjust military court proceedings. Allowing unification of different factions in the republic under a common national cause, the Slovenian communist leaders improved their rating in the eyes of the Slovenian public, which, increasingly felt that it had common interests with the party elite ${ }^{47}$. Encouraging mobilization, Slovenian elites broadened the social base of the regime and strengthened their power position. At that moment, the Slovenian leadership could not only tolerate the mobilization of the Slovenian pluralistic society, but could also initiate further liberalization ${ }^{48}$. Confident that they would still gather most of the electoral support, and following a reform strategy, the Slovene party elites at the end of 1989 decided to allow multi-party elections for the republican assembly ${ }^{49}$. As a result, the Slovenian transition would «most closely parallel the Hungarian method of gradual evolutionary change and internal party reform $»^{50}$. More importantly, this transition has "occurred by way of national mobilization and it would be impossible to imagine that it could have been successful otherwise $»^{51}$. On its way to became a democratic political elite, the Slovenian party leaders « emerged as defenders of national interests " and "found their legitimization basis in nationalism $»^{52}$. The Slovenian party elite, in the period between 1988 and 1989, in the midst of legitimization crisis and under Serbian threat, opted for liberalization as the only choice out of the crisis. However, it is important to note, that the liberal wing of the Slovenian communist party that came into power in the 1980's proceeded with reforms of the system only after it had successfully mobilized the Slovenian pluralistic society in favor of the particular solution to the Yugoslav crisis advocated by the party. This fact has convinced the Slovenian elite that they could win competitive elections, if they moved to a democratic system of governing ${ }^{53}$.

Following the "military affair" in September 1989, the Slovenian leadership strengthened its bargaining position in the Yugoslav debates by passing amendments to the Slovenian constitution unilaterally granting the Slovenian republic the right to secession and the right to approve or disapprove proclamation by federal authorities of extraordinary measures in their republic. Thus, while Serbian national leaders broke the Yugoslav status quo by centralizing Serbia's position against its autonomous provinces Kosovo and Vojvodina, and asking for a similar centralization on a federal level, Slovenia responded with assertion of its own rights in relation to the federation. Although motivated and executed in different fashions, both these streams carried dangerous implications for the Yugoslav unity as a whole.

Serbian response to the new Slovene amendments worsened the situation even further. The pro-Milošević Serbs and Montenegrins from Kosovo declared their intention to hold a protest rally in Ljubljana on December $1^{\text {st }}$, where they thought to bring 30-40 000 of their fellow co-nationals from Serbia and Kosovo to inform the Slovenes about the situation in the province of Kosovo. In reaction, the Slovenian party elite banned the meeting and exposed their view that the protest rally would be considered as "an act of civil war" ${ }^{\prime 4}$. As counter measure, Serbian leadership asked Serbian enterprises to severe business contracts with Slovenia. A month later, in January 1990, the $14^{\text {th }}$ (Extraordinary) Congress of the League of Communist of Yugoslavia only confirmed the already existent split among the regional party organizations. The congress witnessed conflicts among the Serbian and Slovenian delegates on the reform issues and ended with the Slovenian delegation walking out of the meeting. Twelve days later the 
Slovenian party withdraw from the league, renamed itself into a Party of Democratic Renewal, and turned its back to all-Yugoslav politics. With the falling apart of the LCY, Yugoslavia de facto ceased to exist in the form that Tito has conceived it ${ }^{55}$. The open question was whether it could remain a piece in any form whatsoever?

\section{Macedonian Chooses a Middle Way and Liberalizes}

Slovenian liberalization was largely influenced by a reaction to the growing Yugoslav crisis that included close interaction between Slovenian party elites and civil society. Albeit instated by different motives, this interaction also took place in Macedonia. It is important to note that in the immediate post-Tito period the Macedonian party elites followed a conservative course of action, thus favoring the preservation of status quo of Yugoslav politics, i.e., decentralized and communist Yugoslavia. However, in the second half of the 80 's, the combination of the effects of the Macedonian media liberalization and the "pluralization" of the Macedonian society deepened the chasm between the liberal and the conservative camps in the communist leadership ${ }^{56}$. Since the more liberal fraction of the Macedonian communists prevailed in the conflict and took over the party, it begun changing the course of Macedonian politics ${ }^{57}$. Represented by a new generation of young leaders like Vasil Tupurkovski, Petar Gočev, Ǵorg̈i Spasov, and Branko Crvenkovski, the Macedonian party leadership now reoriented its policies towards reforms of the system, though still favoring the 1974 Yugoslav constitutional arrangements which left wide powers to the regional centers.

Contrary to the Macedonian party policy immediately after Tito's death, Macedonian party elites in the second half of the 1980's advanced pro-reform ideas. Thus, for example, in 1985, the Macedonian representative to the Socialist Alliance of Workers People of Yugoslavia (SAWPY) Aleksandar Grličkov, argued against the public monopoly of the ruling party and assessed that a non-communist could not stand a chance to become member of the republican leadership of the SAWPY. He proposed greater, up to $50 \%$, participation of "non-communists" in the SAWPY ${ }^{58}$. By the end of 1980's Macedonian communist leaders were well aware of the structural crisis of the party and advocated reforms. In March of 1988, Petar Gočev, a member of the Presidency of the Central Committee, stressed the need for reforms within the economical and political system of the country ${ }^{59}$. In October of the same year Vasil Turpurkovski, Macedonian member of the collective Yugoslav presidency, explained the need for democratization of the communist party. Speaking about the crisis in Yugoslavia, in November, 1988, Tupurkovski, exposed the idea of reforms and a change to "democratic centralism, i.e., inner party democracy"

The rise of Serbian nationalism alarmed Macedonian party elites about the potential danger of a significant decrease of the status of Macedonia within Yugoslavia ${ }^{61}$. Serbian nationalist leaders alienated Macedonians by trying to pass a federal law that could have allowed Serbian colonist who had acquired land in Macedonia and Kosovo during first Yugoslavia to reclaim their land. Furthermore, in October 1989, the Serbian leadership « intensively backed a proposal to declare $1^{\text {st }}$ December - the day on which Yugoslavia was first united in 1918 - a national holiday ${ }^{62}$. Since the Kingdom of Yugoslavia had mistreated the rights of Macedonians, even degrading them to the rank of "south Serbs", Macedonian party elites became anxious about the possible outcomes 
of the Yugoslav crisis. In response, they mobilized the Macedonian pluralists society to promote the "Macedonian case" within the federation.

Thus, in line with robust nationalist tendencies in the other Yugoslav republics, Macedonian elite presented to the Macedonian public a similar strategy. Macedonian party leaders took advantage of the increasing human rights activity of the Macedonian diaspora, which in the late 1980's begun promoting the interests of the Macedonian minorities in neighboring countries, Greece in particular, to advance Macedonian agenda within the Yugoslav framework. Encouraged by the success of the First International Reunion of Child Refugees of Aegean Macedonian, throughout the second half of 1988, the Macedonian party leadership increasingly begun speaking about the status of the Macedonian minorities in neighboring countries ${ }^{63}$. Pressured by the Macedonian republican government, the Yugoslav representative to the United Nations, in November 1989, accused Greece to oppress the human rights of the Macedonian minority in Greece ${ }^{64}$. Macedonian public responded quickly and with even stronger national sentiments. Throughout 1989 at soccer matches of Vardar Skopje radicalized Macedonian youths chanted nationalist slogans like «Solun [Salonika] is ours ", « Prohor Pćinjski [a monastery near the border with Serbia which since 1953 has been part of the northern republic] is Macedonian", and "united Macedonia " ${ }^{65}$. Graffiti with similar content appeared on the walls of Skopje, but the authorities refrained from hostile actions ${ }^{66}$. In May 1989 an international delegation of Aegean Macedonians presented the problem of the Macedonian national minority in Greece to the Centre for Human Rights in Geneva and met with representatives of the European Parliament in Strasbourg. The Macedonian party elite sympathized with the human rights efforts of the Aegean Macedonians. Thus, Vasil Tupurkovski, in a speech delivered to the Yugoslav Federal Assembly, in late October, criticized the manifestations of extreme Macedonian nationalism, but, still, emphasized the need for more coherent Yugoslav policy on the question of the discrimination of the Macedonian minority rights in Greece, and Bulgaria ${ }^{67}$.

In 1989, Macedonian leadership changed the republican constitution so that Macedonia was redefined as the state of the "Macedonian people" in place of the previous "a state of the Macedonian people and the Albanian and Turkish minorities". Macedonian party ideologist Svetomir Shkarik explained the changes : "Macedonia is to be defined as a state, and the only bearer of this statehood should be the Macedonian nation. That is why the new definition excludes the sovereignty of the nationalities in Macedonia ${ }^{68}$. Similarly to the other republican leaders' reactions to the tense Yugoslav situation the Macedonian party elites too strengthened the legal position of the titular nationality in Macedonia, the ethnic Macedonians ${ }^{69}$. Hence, by changing the constitutional amendments, and thus preserving Macedonian interests against any potential manipulations by the Macedonian minorities, the party showed that it cared about the interests of the Macedonian people.

31 Having defeated the more conservative forces within the party and given the fact that in the late 1980's the Macedonian communists strongly sustained Macedonian national interests, the liberal faction in power felt confident that the introduction of multi-party elections would not significantly change their authority position within the Macedonian society. Consequently, already in early 1989, Vasil Tupurkovski begun advocating pluralism as the solution to the degenerating situation in the Yugoslav federation ${ }^{70}$. Throughout 1989 Tupurkovski repeatedly noted that de-monopolization of 
the party and "pluralization" of the society should be the top priority on the agenda ${ }^{71}$. By mid-1989, the Macedonian communists were deeply committed to the introduction of a multi-party system in Macedonia ${ }^{72}$. In December of 1989 , just before the $14^{\text {th }}$ Congress of the Yugoslav communist party, Gočev, acting as the new elected president of the Macedonian Central Committee, declared that Macedonia supported reforms ${ }^{73}$. Moreover, in February, 1990, immediately after the break up of the League of Communist of Yugoslavia, Gočev announced that the Macedonian communist party would transform into a modern social democratic party and contest in the republican multi-party elections scheduled for the fall of that year ${ }^{74}$.

\section{Slovenia Democratizes ; Prefers Independence 1990-1992}

As we have seen, the process of liberalization in Slovenia and Macedonia was peaceful and gradual. In both republics the party elites played a salient role in transforming the "one party" rule with multi-party elections. Also, both party elites expected to win the democratic contest and remain in power. As a matter of fact, on the eve of the spring elections in 1990, Slovenian reformed communist seemed designated to win; they had a powerful organizational structure, reform oriented program, a strong national agenda in the negotiations with the other Yugoslav republics, and a quite popular leader. However, some of the already mobilized different fractions of the pluralist society that now structured as parties, presented to the Slovenian public even more radical program in favor of reforms and the Slovenian national agenda. Thus, DEMOS, an "umbrella" type of coalition, comprised of six different non-communist parties, with its radicalized version of the Slovenian communist nationalism, managed to "hijack" much of the central stage of Slovenian politics. DEMOS made it clear that Slovenia's priorities laid outside the existing concept of Yugoslavia. As a top DEMOS official explained: "Yugoslavia as a concept is exhausted. Slovenia simply wants to join Europe and is not willing to wait for the rest of Yugoslavia to catch up with it $»^{75}$. The president of DEMOS advocated an independent Slovenia, although not "secession at any cost" ${ }^{76}$. Moreover, DEMOS appeared to be more nationalistic then the reformed communists in the sphere of minority rights asking for abolition of special laws protecting the republic's ethnic minorities.

Not surprisingly, the 1990 Slovenian multi-party elections produced uninstructive results: while the parliament and, hence, the government, became dominated by DEMOS, the presidency was won by the reformed communist candidate Milan Kučan. The uninstructive results of the Slovenian elections inaugurated a new leadership which took even tougher stand on the possibility of keeping Yugoslavia together. Thus, in the period between April 1990 and June 1991, the new Slovenian leadership prepared for independence - on diplomatic, legislative, and military level - rather than focusing its energy to try to preserve Yugoslavia. Although, the Slovenian government continued to offer different solutions for the Yugoslav crisis, like advocating a model of very loose confederacy, given the Serbian factor, it still did it halfheartedly - hoping for the best, but preparing for the worst. In July 1990, the new Slovenian parliament adopted three amendments to the Slovenian constitution which invalidated all federal Yugoslav laws and acts of federal organs that were contrary to the constitution and laws of republic of Slovenia ${ }^{77}$. A joint Croatian-Slovenian proposal for further 
decentralization of Yugoslavia followed in October. After the Serbian side responded with the idea favoring a model of "modern federation" which upheld the notion of "one man one vote", in December 1990, Slovenia further pressed the question of its own prerogatives first, and the federation later ${ }^{78}$.

In December, 1990, in a national referendum more than $88 \%$ of Slovenians voted in favor of a future independence. In fact, by dawn of 1991 Slovenia already behaved as an independent state :

it began withholding the federal customs duties and other payments from Belgrade, set up independent institutions for the conduct of its foreign policy (including a number of quasi-diplomatic offices abroad), and began preparations for the establishment of a Slovenian army and the introduction of a separate currency ${ }^{79}$.

On $26^{\text {th }}$ of December the Slovenian legislature adopted a declaration of its republic's sovereignty ${ }^{80}$. In February 1991 the Slovenian parliament adopted a resolution calling for a consensual disassociation of Slovenia from the rest of Yugoslavia. Moreover, fearing that the Yugoslav crisis might get out of control despite the series of summit talks between all the Yugoslav republican presidents aimed at finding a formula for a future Yugoslav union, the Slovenian leadership, in May 1991, proposed a deadline of $26^{\text {th }}$ of June for the other republics to agree to a confederation ${ }^{81}$. When, eventually, the new republican leaders could not find a compromise, on $25^{\text {th }}$ of June, Slovenia declared independence, disassociating from Yugoslavia. Following a brief military conflict against the increasingly pro-Serbian federal army, Slovenia managed to arrange the withdrawal of the Yugoslav army troops, and, therefore, accomplish a de facto independence from the other Yugoslav republics ${ }^{82}$.

With the question of Slovenian participation in a future Yugoslav state put aside, the new Slovene elites could concentrate on more pressing matters, reforms of Slovenian system. As a result of the unclear results of the elections, there were long and extensive deliberations concerning the nature of the new Slovenian constitution among the different parties represented in the parliament. Finally, the new Slovenian constitution was adopted on $23^{\text {rd }}$ of December 1991. The constitution brought a compromise between two fundamentally different views on how a democratic policy should arrange and regulate itself; one advocated by the parties right of the center, advocating significant role of the Catholic Church in state affairs including such issues as abortion and religious education, and the other championed by the reformed communist, in favor of gradual transformation of the slovene society and building a social democracy ${ }^{83}$.

The uninstructed results of the Slovenian elections resulted in the new Slovenian constitution being stable and balanced introducing checks and balances and maximizing the influence of minorities ${ }^{84}$. The new constitution transformed Slovenia into a parliamentary democracy and « incorporated the existing standards in the field of human rights $»^{85}$. In order to insure the protection of human rights the Slovenian legislature introduced the institution of a Human Rights Ombudsman ${ }^{86}$. After significant debates between proponents of unicameral and proponents of bicameral assembly it was decided that the parliament would be unicameral. However, the work of the national assembly which had legislative powers, was to be checked and balanced by the newly formed Council of State. The council, as an advisory body, had an authority to review, and if deemed necessary, return pieces of legislation to the 
national assembly. Furthermore, the new Slovenian elites, introduced rules ensuring an independent judiciary and media.

Finally, the Slovenian new elites, embracing both the DEMOS coalition and the reformed communist presidency, agreed on their basic policy orientations : European integration and economic transformation and privatization. Although having different approaches to the pressing issues, the Slovenian elites established consensus, a pact, concerning the fundamental values of the Slovenian democratization process : both, the opposition and the coalition in power favored independent, democratic and promarket economy and European Union membership for Slovenia. Although in Spring of 1992 the ruling coalition split, and the government fell, the early established consensus was not broken. The new Slovenian coalition government formed in early 1993, still continued to steer Slovenia on the already paved path of democratization. In fact, the EC recognition of Slovenia as an independent state, on $15^{\text {th }}$ of January 1992, marked the end of the first phase of Slovenian democratization : the new government would carry on issues of democratic consolidation only.

\section{Macedonia Opts for Preservation of Yugoslavia ; Democratizes}

Liberalization of Macedonian society and the introduction of multi-party system brought to the public scene different opposition views. Among the first to organize into a political association was a fraction of the Macedonian intellectuals concerned with the well being of the Macedonian nation and the state. On $4^{\text {th }}$ of February 1990, the more nationally oriented Macedonian intelligentsia founded the MAAK party (Movement for Pan-Macedonian Action). The core of the party was recruited from the sections of the Macedonian Writers Union that in the late 1980's voiced strong proMacedonian sentiments. Not surprisingly, therefore, MAAK criticized Bulgaria and Greece on their human rights records, while in the same time favoring more Macedonian course of action on the Yugoslav scene.

Meantime the Macedonian communist leaders continued with the policy of mobilization of the Macedonian society affirming Macedonia and its interests within the Yugoslav federation. On $20^{\text {th }}$ of February the Macedonian party elites organized a mass rally in the center of Skopje ${ }^{87}$. These demonstrations, attended by some 75000 people, promoted Macedonian identity and protested against the oppression of ethnic Macedonians in Greece, and Bulgaria ${ }^{88}$. The protest was tacitly prepared to coincide with the visit of the Greek Prime Minister to the Yugoslav federal government in Belgrade $^{89}$. Another mobilization of the Macedonian public occurred in May the same year, when « 50000 Macedonians blocked the border crossings between Yugoslavia and Greece in an effort to convince the Greek government to recognize its Macedonian minority and to persuade the Yugoslav government to pressure the Greek government to move in this direction as well $»^{90}$. Macedonian communists also reacted upon Serbian nationalist designs on Macedonia. Thus, in a speech held on $2^{\text {nd }}$ of June, Petar Gočev, not only castigated Bulgaria, and Greece, but also warned about the potential danger coming from the north ${ }^{91}$.

The same month the Macedonian leadership, "internationalized" its care for the Macedonian national interests. At the second meeting of the Conference on the Human Dimension, held in Copenhagen in June of 1990, the Macedonian influenced Yugoslav 
delegation again raised the issue of minority rights in Greece and Bulgaria. In corporation with Macedonian minority activists from different countries, the Yugoslav delegation introduced a "Memorandum Relating to the Macedonian National Minority" which accused the governments of Bulgaria and Greece of a number of specific violations of the human rights of the members of the Macedonian national minorities living in their countries ${ }^{92}$. Mobilizing the Macedonian society and appearing on the forefront of the defense of Macedonian national interests, Macedonian reformed communist party looked with much hope upon the upcoming multi-party elections.

In late June 1990, another nationalist party emerged on the Macedonian scene. Supported by the Macedonian emigration and founded by such eminent Macedonian dissidents as Dragan Bogdanovski and Goran Jakovlevski, the new party was named VMRO-DPMNE (Internal Macedonian Revolutionary Organization - Democratic Macedonian Party for Macedonian Unity) ${ }^{93}$. The party platform previously published in the March issue of Mlad Borec largely related to the ideals of the historical VMRO, nationalist organization that had aimed to liberate Macedonia from the Ottoman rule ${ }^{94}$. Led by the charismatic, young leader, Ljubčo Georgirevski, VMRO-DPMNE, pledging to work for the ideal of "all free Macedonians united", overshadowed the national agendas of both MAAK, and the reform communists. The party also asked for immediate improvement of Macedonian relations with Slovenia and Croatia, and for the return of the "Macedonian territories" within the Serbian boundaries".

On the eve of the first multiparty elections in Macedonia, held in November 1990, over twenty parties were operating in the country. The reformed communists (League of Communists of Macedonia - Party of Democratic Transition, SKM-PDP) run on a platform that sought recognition for Macedonian sovereignty in some type of "Yugoslav framework"96. Similar platform was exposed by the Macedonian Alliance of Reform Forces, an economically oriented party that had connection to the only party that was based throughout Yugoslavia, and was founded by the then federal premier Ante Marković. SKM-PDP opted for a Macedonian identity and dignity and promised to organize Macedonia as a

sovereign state which accepts union with other peoples of Yugoslavia only on voluntary and equal basis, and of course with the right of secession... Yugoslavia is possible only as a union of sovereign states with those delegated and agreed powers at the union level that each of the several members of the union is willing to delegate without pressure ${ }^{97}$.

Although SKM-PDP, promoted Macedonian interests, it was still careful enough to leave an open door for the possibility of a transformed Yugoslav state.

The SKM-PDP opponents were those parties which had intrinsically even more Macedonian agenda on their program, MAAK, and VMRO-DPMNE. The moderate but still nationally minded MAAK advocated "a spiritual union of all Macedonians" in a sovereign Macedonian state that would be part of confederate Yugoslavia but no longer subject to Serbian "hegemonism"98. VMRO-DPMNE, too, was committed to Macedonian sovereignty, but not necessarily within a Yugoslav confederation only: the party envisioned a broader confederate union of Yugoslavia, Bulgaria, and Greece, which would de facto bring all Macedonians in the region under the auspices of a single state. As an only alternative to this project VMRO-DPMNE discussed a complete separation from Yugoslavia ${ }^{99}$. Supported by Macedonians from the diaspora, and largely playing with nationalist rhetoric, VMRO-DPMNE send appealing messages to large segments of Macedonian society. The party's stand against the largely perceived as illegal Kosovar 
Albanian immigration into Western Macedonia, in favor of return of property of dispossessed Macedonians in Greece, and the "spiritual, economic, and ethnic union of the divided Macedonian people and the creation of a Macedonian state in a future united Balkans and united Europe », significantly increased VMRO-DPMNE's popularity among the Macedonian voters ${ }^{100}$.

Not surprisingly the results of the parliamentary elections showed how much the Macedonian communist elite had underestimated the potential strength of parties that put even more emphasis on the Macedonian matters than SKM-PDP ${ }^{101}$. Although in the late 1980's Macedonian communists led the republic on a relatively reasonable course, and, in 1990, offered the Macedonian public very sensible solutions to the frantic Yugoslav situation combining it with a strong pro-Macedonian preelection agenda, SKM- PDP still could not win the 1990 parliamentary elections. Riding on a nationalist ticket VMRO-DPMNE was the most successful party obtaining 38 seats ( 31,7 percent) in the legislature, followed by the reformed communist with 31 seats $(25,8$ percent), a coalition representing the interests of the Macedonian Albanian minority with 23 seats $(18,3$ percent $)$ and the economically oriented Alliance of Reform Forces with 17 seats (14,2 percent).

The outcome of the election produced rather highly fragmented and unclear results ${ }^{102}$. The new Macedonian leadership, that came about with successful negotiations of the parties gaining most at the elections, had a more or less similar approach to the Yugoslav crisis as the pre-election stance of the Macedonian communist. The new Macedonian elite still insisted on some sort of consensus on the status of Yugoslavia, while maintaining its independent course of action. On January $25^{\text {th }}, 1991$, the parliament adopted a Declaration of Sovereignty which stated that the independence and the territorial integrity of the Macedonian people, based upon their right to selfdetermination and secession, should be guaranteed in a forthcoming constitution and validated through a popular referendum. The declaration also anticipated an equal role for Macedonia in the inter-republican negotiations on Yugoslavia's future.

Shortly after the adaptation of the Declaration of Sovereignty, on January $27^{\text {th }}, 1991$ Macedonian assembly elected Kiro Gligorov president of the country. Immediately upon his inauguration Gligorov won the support of the parliament and dedicated his efforts to a three point plan : preservation of Yugoslavia through a peaceful resolution of the crisis, creation of a parliamentary democracy secured by adoption of a new constitution, and promotion of the rights of national minorities in Macedonia ${ }^{103}$. Aware of the perils for Macedonia if Yugoslavia disintegrated, Gligorov, together with Alija Izetbegović, the president of Bosnia and Herzegovina, concentrated in mediating between the two sides holding opposed views on the future status of Yugoslavia, Slovenia and Serbia. On June $3^{\text {rd }}$ Gligorov, together with Izetbegović, proposed a new Yugoslav framework which would have included a common army, currency, and foreign policy ${ }^{104}$. However, throughout 1991, despite the Gligorov and Izetbegović's mediating efforts, the political rift between the two opposing sides of the Yugoslav conflict only widened. Yugoslav Army's intervention in Slovenia in June, 1991, and the multiplication of armed skirmishes between Serbian irregulars and police authorities in Croatia only worsened the already tense situation.

Faced with an increasingly violent deterioration of the crisis in Yugoslavia, which could have had dangerous implications on Macedonian security, in the spring of 1991 Gligorov insisted on, and succeeded in, forming a government representing all 
parliamentary parties as a kind of a "national front" for achieving Macedonia's strategic aims. The "government of experts" represented the broad consensus among the Macedonian parties concerning the fundamental Macedonian policy orientations and in support for democratic and sovereign, or in case of a break up of Yugoslavia, independent Macedonia, the rule of law, market economy, and joining the European system. The constellation of powers in the new government and the presidency came about as a result of a party pact between the leading Macedonian parties ${ }^{105}$.

Following the violent summer of 1991, when fighting erupted first in Slovenia, and then throughout Croatia, Gligorov and the new Macedonian government, decided to go ahead with the plans for obtaining independence. On September $8^{\text {th }}, 1991$, a referendum was held in which more than $95 \%$ of those voting voted for a sovereign and independent state. On September $17^{\text {th }}$, the same year Macedonian parliament, the Sobranie, adopted a Declaration on the proclamation of the results of the referendum. The uninstructive results of the 1990 parliamentary elections brought the major Macedonian parties to adopt more balanced and stable constitution ${ }^{106}$. The new Macedonian constitution promulgated on $1^{\text {st }}$ of November, 1991, and brought as a result of complicated debates between the major Macedonian parties, established Macedonia as a parliamentary democracy and provided space for "cohabitation" between the Macedonians and the minority groups within the country ${ }^{107}$. Modeled on constitutions of well established democracies, the Macedonian supreme legal document introduced a system of checks and balances, dividing the executive, legislative, and judiciary powers ${ }^{108}$. Furthermore, according to the constitution, the principle of human rights and freedoms, was the "basis on which the social organization of the Macedonian society must be built ${ }^{109}$. In order to serve the interests of the ethnic minorities, the constitution provided for the establishment of a Council for Interethnic Relations within the legislature ${ }^{110}$. The new constitution also avoided the vacuum in the sphere of legal continuity through successfully resolving the issues of the relationships of the new legal order vis-à-vis both the previous federal legal framework and the international laws and conventions.

51 Macedonia completed the democratization process on November, $21^{\text {st }}, 1991$, when it declared independence from rump Yugoslavia. However, unlike Slovenia, which by April 1992 was recognized by the European Community, Macedonia was kept out of the loop, hostage of Greek policy ${ }^{111}$. Because of Greek objections, and despite the EC's Badinter Commission recommendation that argued that among the Yugoslav republics aspiring to become independent only Slovenia and Macedonia met the minimum requirements for recognition as democratic states, Macedonia was not recognized by the EC in 1992. Thus, the process of democratic transition have left the Macedonian elite with a bitter taste in mouth; although Macedonia successfully liberalized and introduced parliamentary democracy, Yugoslavia did not restructure to meet Macedonian interests, and breaking apart, brought to the new Macedonian leadership unique predicaments to be handled in the period of democratic consolidation: problems of international recognition adherence to the UN economic sanctions against Yugoslavia, Greek diplomatic and economic pressure resulting in the imposition of a unilateral embargo in 1994-1995, etc. Consequently, the accumulation of these problems would have a significant impact on the way party politics and minority issues were handled in the period (1992-1996), but, this is not the topic of this paper. 


\section{Conclusions}

52 Macedonian and Slovenian elites followed a distinct path to liberalization and democratization. The road to democracy was paved when in the late 1980's both Macedonian and Slovenian elites embraced multi-party elections, and disregarded the old communist ideology. As Przeworski mentioned, liberalization can occur if the "liberalizers" in the communist party feel secure that they will win competitive elections if «they proceed all the way to democracy ${ }^{112}$. Thus, the decision to liberalize is rather psychological, but as the cases of Slovenia and Macedonia show, plausible. In both countries, the elites have sought to mobilize their societies to promote republican interests in discussions over the future status of the Yugoslav federation. Doing so Macedonian and Slovenian elites have generated enough public sympathy and support to feel secure about the possibility of "opening up" and reforming the system.

Despite initially strong positions and national oriented platforms, Slovenian and Macedonian party elites did not win parliamentary elections in 1990 because of the emergence of parties and coalitions that had even more national programs. Still, the democratic elections in Slovenia and Macedonia produced uninstructive outcomes. As hypothesised by Przeworski, this type of elections' results positively affects the formation of new democratic institutions. The new adopted constitutions in both Slovenia and Macedonia were balanced and stable. Furthermore, in both Macedonia and Slovenia the parties negotiated a pact, or a consensus on the basic policy orientations of the countries, and, in the case of Macedonia, also on the distribution of offices within the government. By gradually transforming the monolith communist system and negotiating elite settlements, the Macedonian and Slovenian elites achieved consensus and unity necessary for the process of democratic transformation ${ }^{113}$. All these factors signify that Macedonia and Slovenia had a distinct but successful transition from communism to democracy.

During the process, Yugoslavia disintegrated as a state and both Slovenia and Macedonia declared independence. While the Slovenian elites were prepared for such an outcome of the Yugoslav crisis, the Macedonian leadership was taken by surprise. If the Slovenian elite, in the debates for the solution of the Yugoslav crisis, opposed Serbia and stressed that if their interests were not taken into account Slovenia would secede, Macedonian leadership tried to mediate the conflict, and find compromise settlement. These different policies towards the Yugoslav crisis had an impact on the democratization processes in Macedonia and Slovenia. After Yugoslavia violently disintegrated both Slovenia and Macedonia asked for recognition from the European Commission. Although the 1991 EC Badinter commission judged both countries as democratic, and recommended their recognition, initially only Slovenia was recognized as an independent country. Moreover, as a result of the policy of the Macedonian party leadership in favor of preservation of Yugoslavia, the new Macedonia elites in the period of democratic consolidation, after Yugoslavia broke down, faced various difficult obstacles including diplomatic pressure from Greece, economic sanctions, and minority issues. As Higley and Pakulski argue exactly, this type of problems effectively slow down the process of democratic consolidation ${ }^{114}$. Therefore, despite the gradual transformation and liberalization of the system, and the early reached elite consensus, Macedonia, unlike Slovenia, experienced difficult period of democratic consolidation (but this is the topic of another inquiry). 


\section{NOTES}

1. See for example Stepan (Alfred), Linz (Juan J.), eds., Problems of Democratic Transition and Consolidation in Southern Europe, South Africa and Post-Communist Europe, Baltimore : John Hopkins UP, 1996 ; Higley (John), Pakulski (Jan), Wesolowski (Wlodzimierz), eds., Postcommunist Elites and Democracy in Eastern Europe, Basingtoke: Macmilan, 1998; or Dawisha (Karen), Parrott (Bruce), eds., The Consolidation of Democracy in East Central Europe, Cambridge : Cambridge UP, 1997, and by the same authors, Politics, Power, and the Struggle for Democracy in South- East Europe, Cambridge : Cambridge UP, 1997.

2. Higley et. al., op.cit., deal with the topic only passim; Atilla Agh in his The Politics of Central Europe (London : SAGE Publishers, 1998), and in Emerging Democracies in East Central Europe and the Balkans (Cheltenham / Northampton: Edward Elgar, 1998) devotes to the issue minimal attention; while Ramet (Sabrina), "Democratization in Slovenia - the Second Stage", and especially Perry (Ducan M.), "The Republic of Macedonia: Finding its Way " (in Dawisha (Karen), Parrott (Bruce), eds., op.cit.) apply more of a historical approach to the process.

3. See Przeworski (Adam), "Transitions to Democracy", in Democracy and the Market, Cambridge : Cambridge UP, 1991.

4. Ibid., pp. 51-52.

5. Ibid., pp. 88-89.

6. Ibid., pp. 89-90.

7. Ibid., p. 90.

8. They have pointed out that the concept of "elite" has been subject of different classifications and methodological approaches (Higley (John) Burton (Michael), « Invitation to Elite Theory ", in Domhoff (William G.), Dye (Thomas), eds., Power Elites and Organizations, Newbury Park: SAGE, 1987). For Vilfredo Pareto, the elite concept is a theoretical construct that refers to the conglomeration of politically effective actors in a society, elites being « the class of people who have the highest indices in their branch of activity ». He also noted that this class can be divided among two components: a governing elite and a non-governing elite. The governing elite " comprises individuals who directly or indirectly play some considerable part in government " (Pareto (Vilfredo), «The governing Elite in Present Day Democracy », in Etzioni-Halevy (Eva), ed., Classes and Elites in Democracy and Democratization, New York : Garland 1997, p.47).

Hence, my discussion of the Macedonian and Slovenian elite's responses to the Yugoslav crisis, and their democratization drives, will focus only on those individuals who could influence these processes as members of the ruling party, in the period until 1990, or, as members of the new governments, in the aftermath of the 1990 elections, knowing that they can be the same.

9. Higley (John), Burton (Michael), «The Elite Variable in Democratic Transitions and Breakdowns ", American Sociological Review, 54, 1989.

10. Burton (Michael), Gunther (Richard), Higley (John), « Introduction : Elite Transformation and Democratic Regimes", in Higley (John), Gunther (Richard), eds., Elites and Democratic Consolidation in Latin America and Southern Europe, Cambridge : Cambridge UP, 1992, p.11.

11. Burton (Michael), Higley (John), «Elite Settlement », American Sociological Review, 52, 1987, p. 297.

12. Higley (John), Pakulski (Jan), «Revolution and Elite Transformation in Eastern Europe », Australian Journal of Political Science, 27, 1992, p. 111.

13. Burton (Michael), Higley (John), art.cit., p. 295.

14. Burton (Michael), Gunther (Richard), Higley (John), art.cit., pp. 15-18.

15. Higley (John), Pakulski (Jan), art.cit., p. 114.

16. Ibid., p. 111. 
17. On these issues see Ramet (Sabrina), Nationalism and Federalism in Yugoslavia 1962-1991, Bloomington / Indianapolis : Indiana UP, 1992, pp. 92-135. On the Macedonian liberalization agenda, its leaders, and suppression see Milosavlevski (Slavko), Dvete Lica na Sobitijata (The Two Faces of Developments), Skopje : Kultura, 1998.

18. See Cohen (Lenard), Broken Bonds: Yugoslavia's Disintegration and Balkan Politics in Transition, Westview Press : Oxford, 1993, p. 47 ; Gow (James), Legitimacy and the Military: the Yugoslav Crisis, London: Pinter, 1992, p. 118; or Sekelj (Laslo), Yugoslavia: The Process of Disintegration, New York : Columbia UP, 1993, p. 207.

19. See for example, Vejvoda (Ivan), «Yugoslavia 1945-1991 - from Decentralization Without Democracy to Dissolution ", in Dyker (David A.), Vejvoda (Ivan), eds., Yugoslavia and After, London / New York : Longman, 1996, pp. 13-15.

20. Ramet (Sabrina), Balkan Babel: Politics, Culture, and Religion in Yugoslavia, Oxford: Westview Press, 1992, p. 10.

21. Ibid., p. 13.

22. Ibid., p. 14.

23. Ramet (Sabrina), Nationalism and Federalism (op.cit.), p. 225.

24. See ibid., pp. 228-234. The Serbian republican assembly passed new amendments to the Serbian constitution on February $23^{\text {rd }} 1990$. See Power (Samantha), Breakdown in the Balkans : A Chronicle of Events January, 1989 to May, 1993, New York : Carnegie Endowment Special Publication, 1995, p. 1. For an excellent description of the "red-black" symbiosis between Serbian communists and nationalists see Dimitrijević (Nenad), "Words and Death : Serbian Nationalist Intellectuals 1986-1991 » in Bozoki (Andras), ed., Intellectuals and Politics in Central Europe, Budapest : Central European University Press, 1998.

25. See Cohen (Lenard), op.cit., pp. 52-55, and Ramet (Sabrina), Nationalism and Federalism (op.cit.), p. 233.

26. See Ramet (Sabrina), Nationalism and Federalism (op.cit.), pp. 232-233, and Cohen (Lenard), op.cit., p. 58.

27. On the punk movement in Slovenia see Mastnak (Tomaz), «From Social Movements to National Sovereignity", in Benderly (Jill), Kraft (Evan), eds., Independent Slovenia: Origins, Movements, Prospects, London : Macmillan Press, 1994, p. 93.

28. Ibid, p. 94.

29. Mastnak (Tomaz), "Civil Society in Slovenia ", in Seroka (Jim), Pavlović (Vukašin), eds., The Tragedy of Yugoslavia, New York : M.E. Sharpe, 1992, p. 52.

30. See Lampe (John R.), Yugoslavia as a History, Cambridge : Cambridge UP, 1996, p. 342, and Ramet (Sabrina), art.cit., p. 191. On the conflict between the Slovenian conservative and liberal factions, see Sekelj (Laslo), op.cit., pp. 210-213.

31. See for example Vukomanović (Dijana), « Democratization and Nation-State Building in the Postcommunist Central- Eastern Europe », in Bianchini (Stefano), Janjić (Dušan), eds., Ethnicity in Postcommunism, Belgrade: Institute for Social Science/ Forum for Ethnic Relations and International Network Europe and the Balkans, 1996, p. 126.

32. Danforth (Loring), « Ethnic Nationalism in a Transnational World : Greeks and Macedonians at the Conference for Cooperation and Security in Europe ", an unpublished essay, Bates College, 1994.

33. Ramet (Sabrina), Balkan Babel (op.cit.), pp. 26-27.

34. See ibid., pp. 91-92.

35. Nova Makedonija, 01/04/90.

36. Although the communist regimes were significantly different in Yugoslavia and in the Soviet Union, and the development of pluralism took different pace in these two countries, it is interesting to make a parallel between the emergence of Komiti and the rise of associations of sport's fans in other communist countries. For example Adam Przeworski's records that in 1987, 
the "Spartakist", the soccer fans of Spartak Moscow, were the first significant autonomous group in Gorbachev's Soviet Union. See Przeworski (Adam), art.cit., p. 58.

37. Nothing has been written so far on the influence of the soccer fans associations on the political developments in former Yugoslavia although some of these groups, like the Croatian "Bad Blue Boys", or Serbian "Delije", were politically vociferous during the Yugoslav crisis in the late 1980's. See Perašović (Benjamin), "Youth Subcultures and the War in Croatia », in Prpić (Katarina), Despot (Blaženka), Dugandžija (Nikola), eds., Croatian Society on the Eve of Transition, Zagreb : Institute for Social Research, 1993. See also Mihailović (Srećko), « The War Started on May 13, 1990 » in Slapšak (Svetlana), Milošević (Milan) et.al., eds., The War Started on Maksimir, Belgrade: Media Center, 1997, who explains the media manipulations of the nationalist tendencies of some of these associations, and the conflict between "Delije" and "Bad Blue Boys" in May 1990, that symbolized the beginning of the violent disintegration of former Yugoslavia.

38. On the Macedonian transnational human rights organizations see Danforth (Loring), The Macedonian Conflict, New Jersey : Princeton UP, 1995.

39. Ibid, p. 105.

40. See Ǵorği (Ajanovski), ed., Den na Razdelenite (Prva Sredba na Decata Begalci od Egejskiot Del Na Makedonija) (Day of the Divided - First Meeting of the Child Refugees from the Aegean Part of Macedonia), Skopje : NIP Nova Makedonija, 1993, pp. 16-17.

41. See Gerovski (Branko), «Waiting a Second Chance in Macedonia », Transitions, 06/10/95, p. 42.

42. See Maleska (Mirjana), «Politički, Kulturni i Međunarodni Okolnosti, koi Vlijaat Vrz Efikasnosta na Sistemot» (Political, Cultural, and International Circumstances that Affect the System Efficacy), in Efikasnosta na Parlamentarnata Demokratija 1991-1992 (Efficiency of Parliamentary Democracy), Skopje : Institut za Sociološki I Političko Pravni Istražuvanja, 1998, p. 159.

43. Ramet (Sabrina), Balkan Babel (op.cit.), p. 24.

44. See Ramet (Sabrina), Nationalism and Federalism (op.cit.), p. 222, and Cohen (Lenard), op.cit., pp. 62-63.

45. Ramet (Sabrina), Nationalism and Federalism (op.cit.), p. 223.

46. James Gow states that the Slovenian party presidency called for the foundation of the committee at one of its emergency meetings, (Gow (James), op.cit., p. 80).

47. Ibid., pp. 80-83, 86 .

48. See for example Seroka (Jim), "Variation in the Evolution of the Yugoslav Parties ", in Seroka (Jim), Pavlović (Vukašin), eds., op.cit., p. 79, or Cohen (Lenard), op.cit., p. 59.

49. See Cohen (Lenard), op.cit., pp. 61, 83, and Gow (James), op.cit., p. 88.

50. Seroka (Jim), "Yugoslavia and its Successor States ", in White (Stephen), Batt (Judy), Lewis (Paul G.), eds., Development in East European Politics, New York : Macmillan, 1993, p. 105

51. See Magaš (Branka), The Destruction of Yugoslavia, London : Verso, 1993, and Cohen (Lenard), op.cit., p. 50.

52. Sekelj (Laslo), op.cit., p. 214.

53. Therefore, Slovenian liberalization falls into a specific "psychological" category. See, Przeworski (Adam), art.cit., p. 65.

54. Ramet (Sabrina), Nationalism and Federalism (op.cit.), p. 242.

55. See for example Gow (James), op.cit., p. 120.

56. See Gerovski (Branko), art.cit., p. 42.

57. Maleska (Mirjana), «Rizikot na Demokratijata : Slučajot na Makedonija " (Danger for Democracy: the Case of Macedonia), in Godišnik na Institutot za Socijalno Pravno Politički Istražuvanja, (1), 1998, p. 160.

58. Ramet (Sabrina), Balkan Babel (op.cit.), p. 15.

59. Nova Makedonija, $01 / 04 / 88$. 
60. Nova Makedonija, 25/11/88, and 10/12/88.

61. Gow (James), op.cit., p. 129.

62. Ramet (Sabrina), Balkan Babel (op.cit.), p. 35.

63. See for example Nova Makedonija, 04/12/90, and 16/12/90.

64. Danforth (Loring), The Macedonian Conflict (op.cit.), p. 106.

65. Poulton (Hugh), Who are the Macedonians ?, Bloomington : Indiana UP, 1994, pp. 172-173.

66. Ibid., p. 173.

67. Nova Makedonija, 25/10/89.

68. Maleska (Mirjana), « Politički, Kulturni i Međunarodni Okolnosti » (art.cit.), p. 11.

69. On the ubiquity of the process in former Yugoslav republics, see Hayden (Robert), «Constitutional Nationalism in Formerly Yugoslav Republics», Slavic Review, 51, 1992. On the dangerous implications of "constitutional nationalism" see Pettai (Vello), «Emerging Ethnic Democracies in Estonia and Latvia », in Opalski (Magda), ed., Managing Diversity in Plural Societies : Minorities, Migration, and Nation- Building in Post-Communist Europe, Ottawa : Forum Eastern Europe, 1998 ; and Hayden (Robert), "The Logic of the Wars in Yugoslavia ", in Bianchini (Stefano), Janjić (Dušan), eds., op.cit.

70. Nova Makedonija, 16/02/89, and 16/03/89.

71. See : Ramet (Sabrina), Balkan Babel (op.cit.), p. 27 ; Nova Makedonija, 10/06/89, and 25/11/89 ; Politika, 25/10/89.

72. Poulton (Hugh), op.cit., p. 172.

73. Nova Makedonija, 10/01/90.

74. Nova Makedonija, 25/02/90, and Večer, 26/02/90.

75. Cohen (Lenard), op.cit., p. 90.

76. Ibid., p. 91.

77. Ramet (Sabrina), «Slovenia's Road to Democracy », Europe-Asia Studies, september-october 1993, p. 4.

78. Serbian proposal was again favoring more centralized, unitary Yugoslav state. Given the numerical superiority of Serbs in former Yugoslavia, any decision making in federal organs that favored the system of "one man one vote", and not consensual agreements, was designed in Serbian interest.

79. Ramet (Sabrina), « Slovenia's Road » (art.cit), p. 5.

80. Cohen (Lenard), op.cit., p. 176.

81. Ramet (Sabrina), « Democratization in Slovenia » (art.cit.), pp. 197-198.

82. Ramet (Sabrina), « Slovenia's Road» (art.cit.), p. 6.

83. Ramet (Sabrina), « Democratization in Slovenia » (art.cit.), p. 199.

84. See Przeworski for a theoretical explanation of cases where the new constitutions are founded when the relation of forces is not known, or the results of the elections are uninstructive, (Przeworski (Adam), art.cit., pp. 87-88).

85. Rizman (Rudolf M.), "Slovenia", in Neuhold (Hanspeter), Havlik (Peter), and Suppan (Arnold), eds., Political and Economic Transformation in East Central Europe, Oxford : Westview Press, 1995, p. 60.

86. Ibid., p. 61.

87. Nova Makedonija, 21/02/90.

88. Ibid.

89. Poulton (Hugh), op.cit., p. 173.

90. Danforth (Loring), The Macedonian Conflict (op.cit.), p. 134.

91. Poulton (Hugh), op.cit., p. 174.

92. Danforth (Loring), The Macedonian Conflict (op.cit.), p. 137.

93. Poulton (Hugh), op.cit., p. 173. 
94. On the development of the $19^{\text {th }}$ century Macedonian national movement climaxed with the foundation of VMRO and its liberation struggle see : Katardžiev (Ivan), Sto Godini od Formiranjeto na VMRO, Sto Godini Revolucionerna Tradicija [Hundred Years of the Foundation of IMRO, Hundred Years of Revolutionary Tradition], Skopje: Misla, 1993 ; Perry (Duncan), Politics of Terror: The Macedonian Revolutionary Movement, 1893-1903, Durham/ London: Duke UP, 1988; and Daskalovski (Židas), Development of Macedonian Nationalism 1814-1913, unpublished M.A. thesis, CEU, Budapest, 1998.

95. Poulton (Hugh), op.cit., p. 173.

96. See : Nova Makedonija, 25/09/90, Večerni List, 08/10/90, Vjesnik, 18/11/90.

97. Cohen (Lenard), op.cit., p. 148.

98. Ibid.

99. Poulton (Hugh), op.cit., p. 176, and Maleska (Mirjana), «Politički, Kulturni i Međunarodni Okolnosti » (art.cit.), p. 156.

100. Perry (Duncan M.), art.cit., pp. 241-242.

101. Ibid.

102. Poulton (Hugh), op.cit., p. 150.

103. Spasov (Ġorgi), "Dilemmas of Independence », East European Reporter, 5 (5), march-april 1992.

104. Cohen (Lenard), op.cit., p. 213.

105. On the importance of party pacts formation on democratic institutions see Przeworski (Adam), art.cit., p. 90.

106. See ibid., pp. 87-88, for a theoretical explanation of this phenomenon.

107. For an commendable discussion on the Macedonian Constitution and the rights of minorities see : Caca (Ǵorgii), « Status and Rights of Nationalities in the Republic of Macedonia », Balkan Forum, (2), 1996.

108. Čokrevski (Tomislav), « Redefinition of the Function of Law in Countries in Transition : the Case of the Republic of Macedonia », Balkan Forum, (2), 1996, p. 148.

109. Ibid., p. 146.

110. Goldman (Minton F.), Revolution and Change in Central and Eastern Europe, New York : M.E. Sharpe, 1997, p. 325.

111. Perry (Duncan), art.cit., p. 234.

112. Przeworski (Adam), art.cit., p. 65.

113. Higley (John), Pakulski (Jan), art.cit. p. 111. On comments on Slovenian elites, see ibid., p. 114 ; and Higley (John), Pakulski (Jan), «Elite Power Games and Democratic Consolidation in Central and Eastern Europe », paper presented at the $14^{\text {th }}$ World Congress of Sociology, Montréal, 1998, p. 17.

114. Higley (John), Pakulski (Jan), « Revolution and Elite Transformation » (art.cit.), p. 111.

\section{ABSTRACTS}

The author explains the distinct democratic transition of Slovenia and Macedonia using Przeworski's theory of democratization. He underlines the differences and similarities between the paths of transition followed by these two former Yugoslavian republics. He also shows the importance of the elite's responses to the status of second Yugoslavia in the frame of this process 
INDEX

Geographical index: Macédoine, Slovénie, Yougoslavie

Mots-clés: Elites, Ligue des communistes de Yougoslavie, Pluralisme politique, Transition démocratique

\section{AUTHOR}

ŽIDAS DASKALOVSKI

Université de Budapest. 